\title{
Prevention of Early Neonatal Hypocalcemia in Low Birth Weight Infants with Continuous Calcium Infusion: Effect on Serum Calcium, Phosphorus, Magnesium, and Circulating Immunoreactive Parathyroid Hormone and Calcitonin
}

\author{
BERNARD L. SALLE. ('2' L.OUIS DAVID, JEAN P. CHOPARD. DENIS C. GRAFMEYER, AND \\ HUBERT RIENAUD \\ Neonatal Departme'nt. Hopital Edonard Herriot, Unite Inserm U.34, Hopital Debrousse', and Laboratoire de' \\ Biochimie A. Hopital Edouard Herriot Lyon. France'
}

\begin{abstract}
Summary
This study was conducted in 41 premature infants during the first $48 \mathrm{hr}$ of life to investigate the effect of a constant calcium infusion on serum calcium, phosphorus, magnesium, immunoreactive parathyroid hormone (iPTH), and immunoreactive calcitonin (iCT) in low birth weight infants (LBW). The infants were divided into two comparable groups. A control group (group $I$ ) included 16 infants who received a $10 \%$ glucose solution; a calcium group (group $I I$ ) included 25 infants who received a $10 \%$ glucose solution with calcium gluconate, the amount of mineral calcium perfused being $35 \mathrm{mg} / \mathrm{kg} / \mathrm{day}$ or 1.7 $\mathrm{mEq} / \mathrm{kg} /$ day. No overall adverse effects were observed in the infants receiving the $\mathrm{Ca}$ infusion.

In the first group, mean serum Ca level decreased rapidly during the first $24 \mathrm{hr}$ of life from $8.9 \pm 0.7 \mathrm{mg} / 100 \mathrm{ml}$ to 6.79 $\pm 1.07 \mathrm{mg} / 100 \mathrm{ml}$ at $22-26 \mathrm{hr}(P<0.001)$ without any further significant change. In the second group, the mean serum $\mathrm{Ca}$ level remained stable from $1-3 \mathrm{hr}(8.51 \pm 0.61 \mathrm{mg} / 100 \mathrm{ml})$ to 44-48 hr $(8.33 \pm 0.94 \mathrm{mg} / 100 \mathrm{ml})$. The mean Ca levels were significantly higher in group $I I$ at 10-14 hr and 22-26 hr $(P<$ 0.001 ). There was no significant change in mean serum $P$ levels in both groups. The mean serum $\mathrm{Mg}$ levels were significantly higher in group II from 22-48 hr. Mean serum iP'TH levels increased in both groups from 1-3 hr to 44-48 hr $(P<0.001)$ without significant difference at any time between the two groups. The mean serum iCT level showed a marked increase from 1-3 hr to 10-14 hr or 22-26 hr in both groups $(P<0.001)$ without significant difference between the two groups. In both groups of infants a negative correlation was observed between serum iCT and serum Ca levels at 22-26 hr. In group I, mean serum iCT levels decreased during the second day of life, whereas in group $I I$ there was no further significant change in mean serum iCT.

These data suggest that the administration of a continuous intravenous perfusion of calcium can prevent early neonatal hypocalcemia in low birth weight infants without depressing the parathyroid activity in the majority of the infants. They also indicate that the hypercalcitoninemia which is observed during the neonatal period is not closely dependent upon the serum Ca level; however, the finding of negative correlations between serum $\mathrm{Ca}$ and serum iCT levels suggests that the elevated serum iCT levels have a depressive effect upon serum $\mathrm{Ca}$ in low birth weight infants.
\end{abstract}

Speculation

The use of a prophylactic continuous calcium infusion has been advocated to prevent early neonatal hypocalcemia of low birth weight infants. In the normal adult calcium infusion is known to depress the parathyroid function and may stimulate the secretion of calcitonin. We wished to determine the effects of early continuous calcium infusion on serum parathyroid hormone and calcitonin levels in low birth weight infants.

Hypocalcemia occurs frequently in LBW infants during the first $48-72 \mathrm{hr}$ of life $(22,3()-32)$. For that reason some authors advocate a prophylactic continuous calcium infusion by peripheral vein in all $I . B W$ infants after hirth (1,20, 23, 27, 29). However, this proposal raises several important questions that have to be answered before it can be fully accepted. (l) What amount of calcium has to be given in order to be effective in preventing early neonatal hypocalcemia without risk of hypercalcemia? (2) Are there local or general complications to fear? (3) Calcium infusion depresses the parathyroid function and may stimulate the secretion of calcitonin in normal adults. Do such hormonal changes occur in the LBW infants under prolonged intravenous calcium infusion? If so, is late neonatal hypocalcemia to be expected once the calcium infusion is stopped? The aim of the present study was to answer these questions. Furthermore. we have examined the possible physiologic effect of a calcium infusion on serum magnesium, phosphorus, parathyroid hormone, and calcitonin levels in LBW infants.

\section{MATERIALS AND METHODS}

The study involved +1 premature and/or small for gestational age neonates, transferred during the first hours of life to the newborn intensive care unit of Fdouard Herriot Hospital (Lyon) from March 1975 to September 1975. The gestational age was assessed by the Dubowitz score (11) (Table 1). According to Lubchencho's growth chart (19), 21 infants were small for gestational age. All but one infant had a birth weight below $2500 \mathrm{~g}$. One infant with a gestational age of 37 weeks had a birth weight of $2700 \mathrm{~g}$.

The elinical characteristics of the infants studied are presented in Table 1. The infants were divided into two groups: a control group. group 1 , included 16 infants who received a $10 \%$ glucose 


\section{Table 1. Clinical characteristics'}

\begin{tabular}{|c|c|c|c|}
\hline & $\begin{array}{l}\text { LBW infants with } \\
\text { (a infusion. } 35 \\
\mathrm{mg} / \mathrm{kg} / \mathrm{day}\end{array}$ & $\begin{array}{l}\text { I.BW infints } \\
\text { without Ca infu- } \\
\text { sion }\end{array}$ & $\begin{array}{l}\text { Student } t \\
\text { test }\end{array}$ \\
\hline No. of intants & 25 & 16 & \\
\hline $\begin{array}{l}\text { Prematures (G A below } \\
37 \text { weeks) }\end{array}$ & 17 & 11 & \\
\hline SCiA infants & 11 & 8 & \\
\hline Weight $(g)$. mean \pm SD & $2000 \pm 392$ & $2013 \pm 351$ & NS \\
\hline Rannge & 1.3()$(0-27(0)$ & $1140-2500$ & \\
\hline $\begin{array}{l}\text { (iA (weeks). meian } \pm \text { SD } \\
\text { Range }\end{array}$ & $\begin{array}{c}36.3 \pm 3.34 \\
32-41\end{array}$ & $\begin{array}{l}36.2 \pm 2.7 \\
28-40\end{array}$ & NS \\
\hline $\begin{array}{l}\text { Respiratory disorders } \\
\mathrm{pH} \text { at birth (mean } \pm \mathrm{SD})\end{array}$ & $\begin{array}{c}8 \\
7.32 \pm 0.015\end{array}$ & $\begin{array}{c}5 \\
7.29 \pm 0.07\end{array}$ & $\begin{array}{l}\text { NS } \\
\text { NS }\end{array}$ \\
\hline
\end{tabular}

'LBW: low birth weight: GA: gestational age: SGA: small for gestational age; NS: not significant. Note that, in each group. three infants were SGA.

solution by a peripheral vein, 11 of the 16 infants were prematures: a "calcium group," group $1 /$, included 25 infants who received a $10 \%$ glucose solution with calcium gluconate added to the infusion: the amount of mineral calcium perfused was 35 $\mathrm{mg} / \mathrm{kg} /$ day or $1.7 \mathrm{mE} / \mathrm{kg} /$ daty. Seventeen of the $25 \mathrm{infants}$ of group // were prematures. The volumes $(80) \mathrm{ml} / \mathrm{kg}$ ) infused by a continuous calcium infusion (Braun pump. Perfusor IV. Melsungen. Germany) and the rate of infusion were similar in hoth groups of infants. Infusions were started immediately after the first blood sampling between 1 and $3 \mathrm{hr}$ of age.

Thirteen of the +1 infants presented pathologic conditions including respiratory distress syndrome or mild transient tachypnea. There was no history of maternal diabetes. For each intant blood $\mathrm{pH}$ was determined just after birth, and wats later checked regularly; corrections were made when necessary using appropriate intravenous bicarbonate infusions. No vitamin D supplement was given during the study. In all infants human milk was commeneed at $12 \mathrm{hr}$ of age.

\section{DI:SIGN OF STUDY}

One to 2-ml hlood samples were drawn from the umbilical arterial catheter, or by peripheral venous puncture using a scalp vein needle at five given periods of time after birth; $1-3 \mathrm{hr} ; 10$ $14 \mathrm{hr} ; 22-26 \mathrm{hr} ; 34-38 \mathrm{hr} ; 4+48 \mathrm{hr}$. Forty infants had their sampling at time $1-3 \mathrm{hr}$; all infants had sequential blood sampling (two to five samples) and a total of 10.3 blood samples were submitted to laboratory analysis.

\section{L.ABORATORY MIIHODS}

The blood samples were centrifuged immediately after collection and the serum was stored at $-28^{\circ}$ until assay. Serum calcium, inorganic phosphorus, magnesium, and total protein were determined by an automatic Technicon SMA 12/60 analyzer, modified for microvolume serum analysis $(400 \mu \mathrm{l})$. Serum Ca was determined by the method of Cindler (18), serum P by the method of Fiske and SubbaRow (14), and serum Mg by the method of Gindler (17). These methods allowed the determination of serum (a and $\mathrm{Mg}$ on very small amounts of serum: we have previously observed that they are accurate and reproducible and that they give a very good correlation with the atomic absorption method $(r=0.986)$. Serum total protein was determined by the method of Weichselbaum $(34)$; hlood $\mathrm{pH}$ by the method of Astrup (25).

Serum immunoreactive parathyroid hormone (iPTH) levels were measured by a radioimmunoassay technique as described by Amaud et al. (2). The guinea pig antiserum (GP6) and the purified bovine PTH used for ${ }^{125}$ I labeling were a gift of $\mathrm{Dr}$. Constantine $S$. Anast from the University of Missouri-Columbia. Department of Pediatrics. In gel filtration studies of serum from patients with primary and secondary hyperparthyroidism performed by $($. S. Anast in his laboratory. (SPf antiserum detected a peak of immunoreactivity that corresponded to the E.I bovine PTH marker (mol wt $96(0))$ and a larger peak that eluted later than the marker. Further immunologic analysis of GPo antiserum showed that the $1-34$ synthetic bovine PTH fragment did not inhibit the interaction of GP6 with ${ }^{12.5}$ I bovine PTH to a significant extent. This indicates that $(\mathrm{PP} 6$ is a carboxyterminal twpe of antiserum which recognizes the 84 amino acid native hormones and the carboxyterminal circulating immunoreactive species $(4,13)$. A human hyperparathyroid serum was used as a standard reference and the concentration of iPTH in unknown serum samples was expressed in microliter equivalents of standard hyperparathyroid serum per ml ( $\mu$ l F.q/ $\mathrm{ml}$ ). The lower limit of sensitivity of the assay was $25 \mu \mathrm{l} \mathrm{E}: \mathrm{y} / \mathrm{ml}$. Approximately $95 \%$ of normal children and adults have detectable values of serum iPTH with an upper limit of 100$) \mu \mathrm{l} \mathrm{E} / \mathrm{g} / \mathrm{ml}$. Mean \pm SD serum iPTH from 37 normal children, aged 7 months to 16 years, was $6.3 \pm 18 \mu \mathrm{l} \mathrm{zy} / \mathrm{ml}$.

Serum immunoreactive calcitonin levels were determined by the radioimmunoassaty technique of Tashjian and Voelkel (28). Synthetic human ( T used for standards and as tracer antigen after 1 iodination was kindly provided by Drs. Rittel and Maier from (iba. Basel. Switzerland. Goat antiserum directed against human ("I has been obtained from Drs. Dietrich and Fisher (Ciha. Basel. and Department of Orthopedic Surgery and Medicine. University of Zurich. Switzerland); a detailed description of this antiserum was published previously (9). Studies of the immunologic specificity of this antiserum performed in our laboratory indicated that large supraphysiologic coicentrations of insulin, glucagon, growth hormone. gastrin. ACTH, or purified bovine PTH did not modify its interaction with rabeled human ( $T$. The antiserum was used at final dilution of $1 / 40.000$. The lower limit of sensitivity of the assay was $150 \mathrm{pg} / \mathrm{ml}$. In this system values of serum iCT were undetectable in normal children and adults. All samples were andyzed under identical conditions. In order to eliminate the effect of interassay and intraassay variations, samples from the same infant were grouped together in the same assay.

\section{CALCUI.ATION AND STATISTICAL ANALYSIS}

For each period of time, results were expressed as mean \pm SD. Paired tests. Student tests, and regression analysis were performed. All calculations were made by submitting the data to an Iris 60 computer (Département d'Informatique. Hospices (ivils de Lyon).

\section{RESULTS}

\section{(;ROUP I: INFANTS NOT RRCGIVING; CALCIUM INFUSION (PAIRFD} TEST ANALYSIS) (35)

Mean serum (a level decreased rapidly during the first $24 \mathrm{hr}$ of life from $8.99 \pm 0.79 \mathrm{mg} / 100 \mathrm{ml}$ at $1-3 \mathrm{hr}$ to $7.07 \pm 0.51$ $\mathrm{mg} / 100 \mathrm{ml}$ at $10-1+\mathrm{hr}(P<0.001)$ and $6.79 \pm 1.07 \mathrm{mg} / 100$ $\mathrm{ml}$ at 22-26 hr $(P \quad 0.0(01)$. There was no further significant change, mean serum (al level at $4+-48 \mathrm{hr}$ was $7.42 \pm 1.03 \mathrm{mg} /$ $100 \mathrm{ml}$ (Fig. 1). There was no significant changes in mean serum $P$ level from $1-3 \mathrm{hr}(5 \pm 0.74 \mathrm{mg} / 100 \mathrm{ml})$ to $22-26 \mathrm{hr}$ $(5.05 \pm 1.17 \mathrm{mg} / 100 \mathrm{ml})$. However. at $44-48 \mathrm{hr}$ a significant increase was observed with a mean serum $P$ value of $5.92 \pm$ $0.64 \mathrm{mg} / 100 \mathrm{ml}(P<0.001)$. Mean serum Mg level showed a small but not significant decrease during the first $24 \mathrm{hr}$ of life from $1.6 \pm 0.12 \mathrm{mg} / 100 \mathrm{ml}$ at $1-3 \mathrm{hr}$ to $1.45 \pm 0.13 \mathrm{mg} / 100$ $\mathrm{ml}$ at 22-26 $\mathrm{hr}$; no significant change in mean serum $\mathrm{Mg}$ level was observed between $22-26 \mathrm{hr}$ and $44-48 \mathrm{hr}(1.54 \pm 0.13$ $\mathrm{mg} / 100 \mathrm{ml}$ ) (Fig. 1). Serum protein levels did not show any significant change at any period of time (Table 2).

All infants studied at $1-3 \mathrm{hr}$ had detectable levels of serum iPTH ranging from 25-240 $\mu \mathrm{l} \mathrm{Fy/ml}$ with a mean of $77.2 \pm$ 


\section{Serum Ca mg/dl}

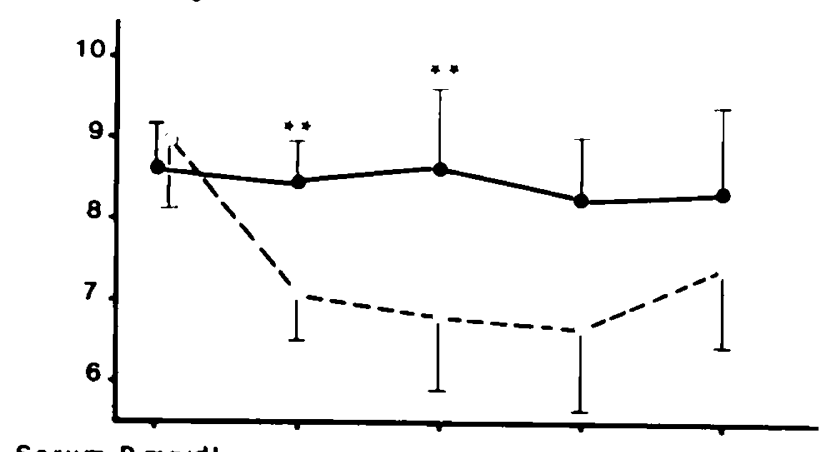

Serum P mg/dl

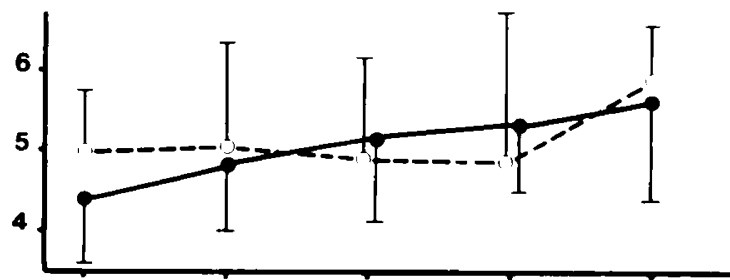

Serum Mgmg/dI

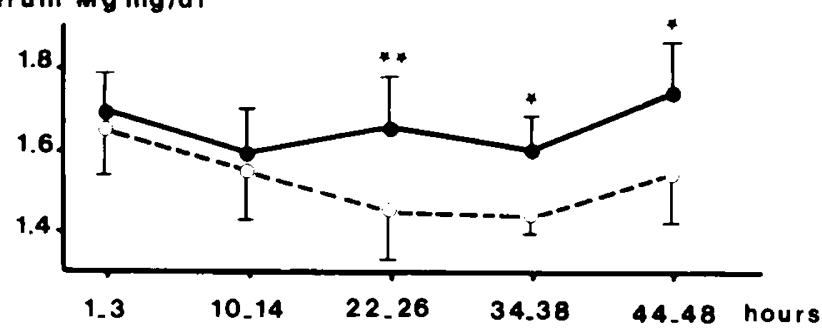

Fig. 1. Serum calcium, magnesium. and phosphorus during the first $48 \mathrm{hr}$ of life in both groups. - - : group $/$ (without calcium infusion): - - group $/ I$ (with continuous calcium infusion); $\star$ : significant difference $(P<0.01) ; \star \star$ : significant difference $(P<0.001)$.

Table 2. Total serum protein (grams per $100 \mathrm{ml}$ ) in both groups during the first $48 \mathrm{hr}$ of life' (me'an $\pm S D)^{\prime}$

\begin{tabular}{|c|c|c|c|}
\hline Time & $\begin{array}{c}\text { LBW with calcium } \\
\text { infusion, } 35 \mathrm{mg} / \mathrm{kg} / \\
\text { day }\end{array}$ & $\begin{array}{l}\text { LBW without cal- } \\
\text { cium infusion }\end{array}$ & Student $t$ test \\
\hline $1-3 \mathrm{hr}$ & $4.80 \pm 0.76$ & $4.98 \pm 0.67$ & NS \\
\hline $10-14 \mathrm{hr}$ & $4.27 \pm 0.41$ & $4.0 \pm 0.52$ & NS \\
\hline $22-26 \mathrm{hr}$ & $4.26 \pm 0.79$ & $4.51 \pm 0.65$ & NS \\
\hline $34-38 \mathrm{hr}$ & $4.22 \pm 0.34$ & $3.85 \pm 0.34$ & NS \\
\hline $44-48 \mathrm{hr}$ & $4.55 \pm 0.75$ & $4.02 \pm 0.7$ & NS \\
\hline
\end{tabular}

' LBW: low birth weight; NS: not significant.

45.9 $\mu \mathrm{l} \mathrm{Eq/ml} \mathrm{(Fig.} \mathrm{2)} \mathrm{(Table} \mathrm{3).} \mathrm{There} \mathrm{was} \mathrm{a} \mathrm{sustained}$ increase in serum iPTH levels from $1-3 \mathrm{hr}$ to $44-48 \mathrm{hr}$, reaching a mean serum $\mathrm{iPTH}$ value of $14.3 .6 \pm 47.9 \mu \mathrm{l} \mathrm{Eq} / \mathrm{ml}(P<$ (0.001). All except 1 of the 16 infants showed an increatse in serum iPTH levels above the $1-3$ hr or $10-1+\mathrm{hr}$ basal values.

Ten of the $1+$ infants studied at $1-3$ hr had nondetectable serum iCT levels $(<150 \mathrm{pg} / \mathrm{ml}) ;+$ infants had detectable levels of serum iCT ranging from $950-30000 \mathrm{pg} / \mathrm{ml}$. In all $1+$ infants there was a marked increase in serum iC T levels from $1-3 \mathrm{hr} \mathrm{to}$ $\mathrm{l}()-14 \mathrm{hr}$ and 22-26 hr. with a peak mean serum ic $\mathrm{T}$ value of $1850 \pm 872 \mathrm{pg} / \mathrm{ml}$ at $10-14 \mathrm{hr}$ (Fig. 3; Table 3). Serum iC T levels decreased during the second day of life. One of the eight infants studied at 44-48 hr had nondetectable serum iCT levels whereas five had detectable levels ranging from $7(0)$ to 2250 $\mathrm{pg} / \mathrm{ml}$. All nine infants studied serially at $10-14 \mathrm{hr}$ and/or 22-26 hr on the one hand, and at 44-48 hr on the other hand, showed a decrease of serum iCT levels $(P<0.001)$.

\section{GROUP II: INFANTS RECEIVING A CONTINUOUS CAL.CIUM INFUSION (PAIRFD TEST ANALYSIS)}

No remarkable local or general complications were observed during and after the infusion. Only one of the 25 infants demonstrated a serum (at level above $10 \mathrm{mg} / 100 \mathrm{ml}$. This particular infant was a small for gestational age term neonate (gestational age: 39 wecks; hirth weight: $1860 \mathrm{~g}$ ); his scrum (at levels were $11.2 \mathrm{mg} / 100 \mathrm{ml}$ at $22-26 \mathrm{hr}$ and $9.6 \mathrm{mg} / 100 \mathrm{ml}$ at $44-48 \mathrm{hr}$. In all but two infants the serum (at level remained above $7 \mathrm{mg} / 100 \mathrm{ml}$.

The mean serum (a kevel remained constant from 1-3 hr $(8.51 \pm 0.61 \mathrm{mg} / 100 \mathrm{ml})$ to $44-48 \mathrm{hr}(8.33 \pm 0.94 \mathrm{mg} / \mathrm{l}(00 \mathrm{ml})$ (Fig. 1). There was a significant increase in mean serum $P$ levels from $+.39 \pm 0.78 \mathrm{mg} / 100 \mathrm{ml}$ at $1-3 \mathrm{hr}$ to $5.6 \mathrm{( \$ )} \pm 1.43$ $\mathrm{mg} / 100 \mathrm{ml}$ at $44-48 \mathrm{hr}$. There was no significant change in mean serum $\mathrm{Mg}$ levels (Fig. 1). Serum total protein levels did not show any significant change at any period of time (Table 2).

All 1.3 infants studied at $1-3 \mathrm{hr}$ presented detectable levels of serum iPTH (mean \pm SD: $75.2 \pm 45.9 \mu \mathrm{lEq} / \mathrm{ml})$. As in group l. there was a steady increase in mean serum iPTH from $1-3 \mathrm{hr}$ to $4+-48$ hr (Fig. 2): this increase was already significant at $10-1+\mathrm{hr}$ with a mean value of $116.2 \pm 56.3 \mu \mathrm{l} \mathrm{Eq} / \mathrm{ml}(P<$ $0.05)$. A mean value of $1.32 \pm 56.2 \mu \mathrm{F} \mathrm{Fy/ml}(P<0.01)$ was reached at $4+-48 \mathrm{hr}$. All except 6 of the $25 \mathrm{infants}$ showed an increase in serum iPTH levels above the $1-3 \mathrm{hr}$ or $10-1+\mathrm{hr}$ basal value (Fig. 2) (Table 3). Only $t$ of the 14 infants studied at $1-3$ hr had detectable levels of serum ic T ranging from 230-2400 $\mathrm{pg} / \mathrm{ml}$. A marked increase in serum iC $\mathrm{T}$ level was observed at $10-1+\mathrm{hr}$. reaching a mean value of $1686 \pm 1327 \mathrm{pg} / \mathrm{ml}(P<$ 0.01). There was no further significant change in serum iCT (Fig. 3) (Table 3).

\section{CORRELATION ANALYSIS}

\section{GROUP I: LBW INFANTS NOT RECEIVING; CAI.CIUM INFUSION (35)}

A negative correlation was found between serum ( $a$ and serum $\mathrm{P}$ levels at $22-26 \mathrm{hr}(r=-0.51 ; P<0.02)$ and $34-38$ hr $(r=-0.96 ; P<0.01)$. There was no correlation between serum $\mathrm{Ca}$ and serum $\mathrm{Mg}$ levels at any period of time. A negative correlation was found between serum (a and serum iCT levels at $10-14 \mathrm{hr}(r=-0.72 ; P<0.05) .22-26 \mathrm{hr}(r=$ $-0.62 ; P<0.01)$ (Fig. 4), and 44-48 hr $(r=-0.86: P<$ $0.01)$. There was a negative correlation between serum $C a$ and serum iPTH levels at $10-14 \mathrm{hr}(r=-0.76 ; P<0.05)$. There

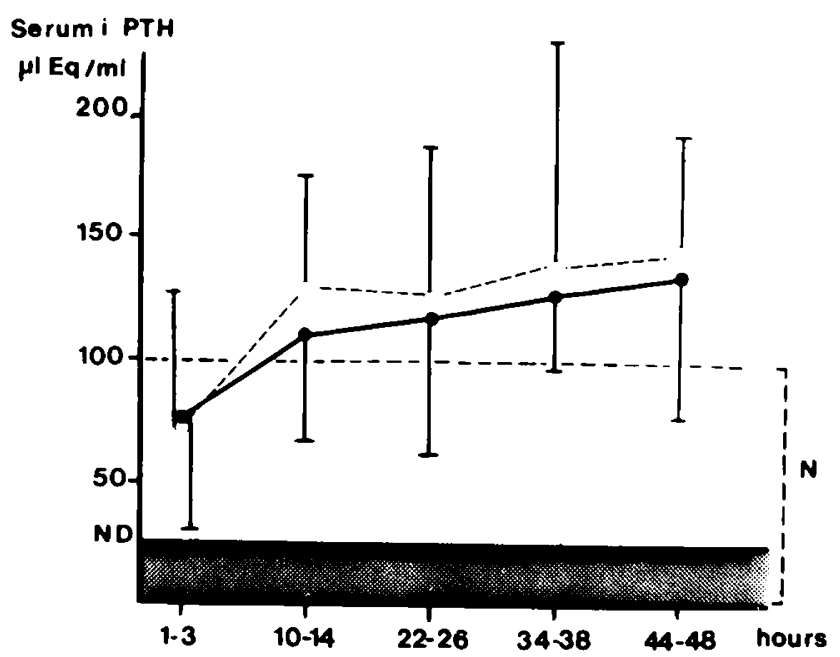

Fig. 2. Scrum immunoreactive parathyroid hormonc (iP'TH) levels in both groups during the first $48 \mathrm{hr}$ of life. - - : group l (without calcium infusion): - : gromp $/ /$ (with continuous calcium infusion). Shadowed area indicates the nondetectable range of assay below $25 \mu \mathrm{l}$ iCT $(\leq 150 \mathrm{pg} / \mathrm{ml})$ 
Table 3. Serum immunoreactive parathyroid hormone (iPTH) and immunoreactive calcitonin (iCT) in both groups in first 48 hroflife'

\begin{tabular}{|c|c|c|c|c|c|c|c|c|c|c|}
\hline & \multicolumn{2}{|c|}{$1-3 \mathrm{hr}$} & \multicolumn{2}{|c|}{$10-14 \mathrm{hr}$} & \multicolumn{2}{|c|}{$22-26 \mathrm{hr}$} & \multicolumn{2}{|c|}{$34-38 \mathrm{hr}$} & \multicolumn{2}{|c|}{$44-48 \mathrm{hr}$} \\
\hline & Group I & Group II & Giroup) I & (iroup $\mathrm{ll}$ & (iroup I & Group II & Group I & Group II & Group I & Group II \\
\hline $\begin{array}{l}\text { No. of patients } \\
\text { iPTH }(\leq 100 \mu \mathrm{l}: \mathrm{y} / \mathrm{ml})\end{array}$ & 14 & 13 & 6 & 11 & 13 & 19 & 4 & 7 & 8 & 7 \\
\hline $\begin{array}{l}\text { iPTH }(\leq 100 \mu \mathrm{E}: \mathrm{y} / \mathrm{ml}) \\
\text { Mean }\end{array}$ & $\begin{array}{l}77.2 \\
\pm\end{array}$ & $\begin{array}{l}75.2 \\
\pm\end{array}$ & $\begin{array}{c}128.8 \\
\pm\end{array}$ & $\begin{array}{c}110.9 \\
\pm\end{array}$ & $\begin{array}{c}125.6 \\
\pm\end{array}$ & $\begin{array}{c}116.2 \\
\pm\end{array}$ & $\begin{array}{c}1.37 .5 \\
\pm\end{array}$ & $\begin{array}{c}126.7 \\
\pm\end{array}$ & $\begin{array}{c}143.6 \\
\pm\end{array}$ & $\begin{array}{l}132.2 \\
\pm\end{array}$ \\
\hline $\mathrm{SD}$ & 45.9 & 58.6 & 71.8 & 4.3 .6 & $6(0.8$ & 56.3 & 90.8 & 29.7 & 47.9 & 56.2 \\
\hline $\begin{array}{l}\text { iCT }(\leq 150 \mathrm{pg} / \mathrm{ml}) \\
\text { Mean }\end{array}$ & $\begin{array}{l}567^{1,2} \\
\pm\end{array}$ & $\begin{array}{c}343^{1 \cdot 2} \\
\pm\end{array}$ & $\begin{array}{l}1850 \\
\pm\end{array}$ & $\begin{array}{c}1686 \\
\pm\end{array}$ & $\begin{array}{c}1462 \\
\pm\end{array}$ & $\begin{array}{c}1272 \\
\pm\end{array}$ & $\begin{array}{c}1178^{1,3} \\
\pm\end{array}$ & $\begin{array}{l}1818 \\
\pm\end{array}$ & $\begin{array}{l}535^{1.3} \\
\pm\end{array}$ & $\begin{array}{c}1590 \\
\pm\end{array}$ \\
\hline SD & 10000 & 708 & 872 & 1.327 & 806 & 1000 & 988 & 860 & 378 & 1127 \\
\hline
\end{tabular}

'For practical reasons, nondetectable values were given a value of zero in calculation of the means. Details for individual values are given in the text (sec Results).

2 Ten values at nondetectable level.

${ }^{3}$ One value at nondetectable level.

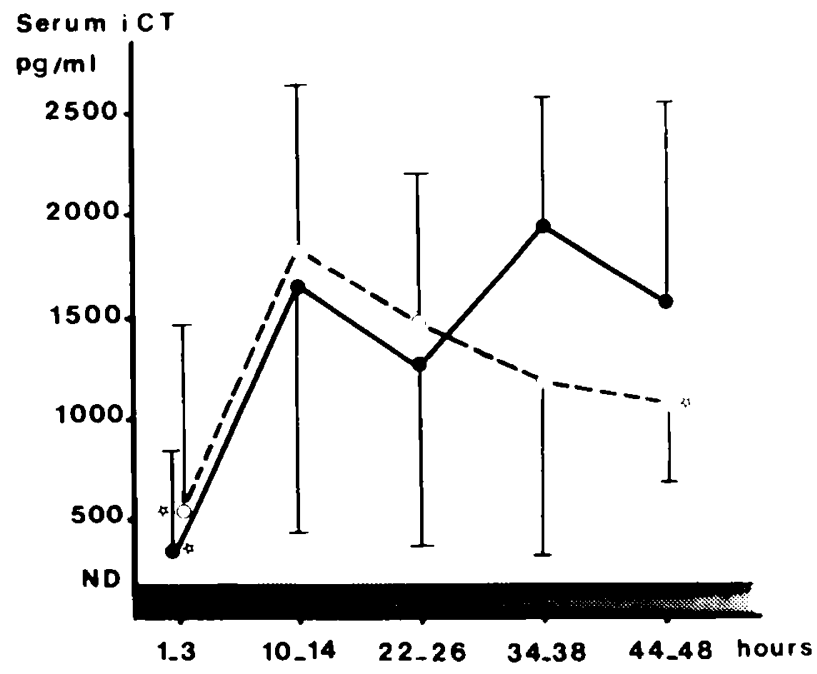

Fig. 3. Scrum immunoreactive calcitonin (i( $T$ ) levels in both groups during the first $48 \mathrm{hr}$ of life. - - - : group I (without calcium infusion); - : group $I I$ (with continuous calcium infusion). Shadowed area indicates the nondetectable range of assaly below $1.50 \mathrm{pg} / \mathrm{ml}$. For practical reasons, nondetectable values (it) were given a value of zero in the ealculation of the means. Details for individual values are given in the text (see Results).

was also a positive correlation between gestational age and serum (a) at 22-26 hr $(r=0.87 ; P<0.01)$.

\section{GROUP II: L.BW INFANTS RECEIVING CONTINUOUS CA INFUSION}

No correlation was observed between serum Ca and serum P levels at any period of time. A positive correlation was found between serum (a and serum Mg levels at $10-14 \mathrm{hr}(r=0.53$; $P<0.05)$ and $22-26 \mathrm{hr}(r=0.36 ; P<0.05)$. There was a negative correlation between serum ( $a$ and serum iCT levels at time 22-26 hr $(r=-0.57 ; P<0.02)$ (Fig. 5). No correlation was found between serum (a levels and scrum iPTH and gestational age at any period of time.

\section{COMPARISON OF (iROUPS I AND $/ I$}

As indicated in Table 1 . the two groups were comparable with regard to gestational age, birth weight, distribution of premature and small for gestational age infants. and incidence of respiratory disorders. There were no significant differences in mean blood $\mathrm{pH}$ at birth. The mean serum (a levels were significantly higher in group $I /$ at $10-14 \mathrm{hr}$ and 22-26 hr $(P<$ 0.01) (Fig. 1). There were no significant differences in mean

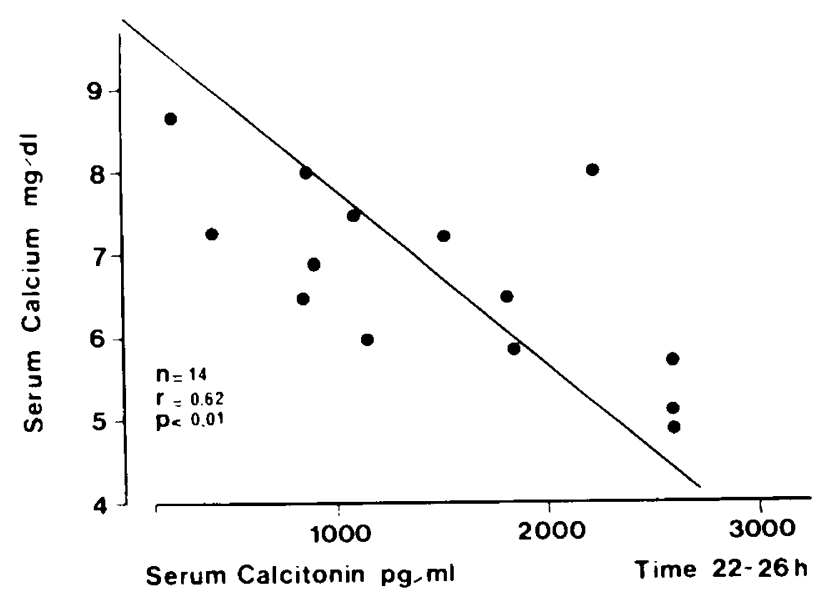

Fig. 4. Relationship between serum calcium and calcitonin at 22-26 hr in group $I$.

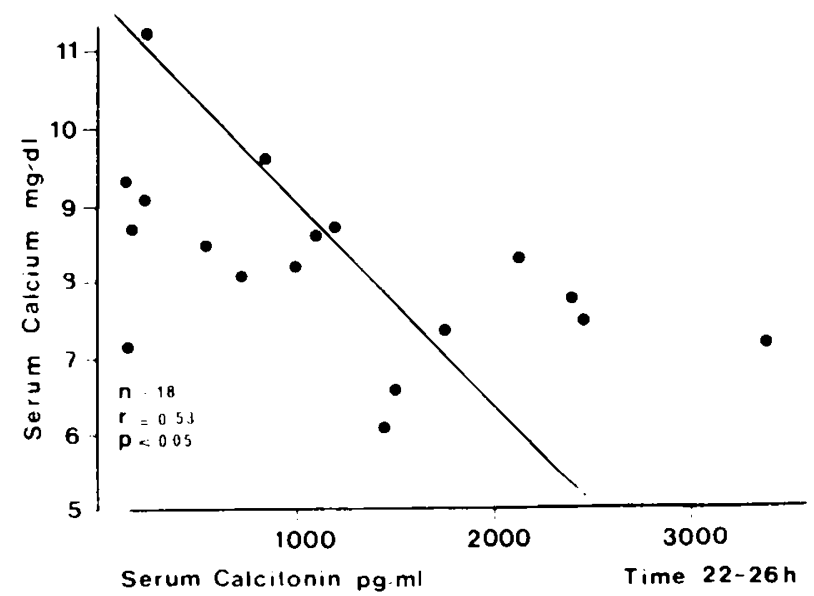

Fig. 5. Reiationship between serum calcium and immunoreactive calcitonin at 22-26 hr in group $/ 1$.

serum P levels at any period of time. By contrast, mean serum Mg levels were significantly higher in group $I I$ at 22-26 hr $(P<$ $0.01), 34-38$ hr $(P<0.01)$. and $4+-48$ hr $(P<0.01)$ (Fig. 1$)$. There was no significant difference in mean serum iPTH and serum i( $T$ levels at any period of time (Figs. 2 and 3 ). 


\section{DISCUSSION}

It is well established that a relative hypercalcemia is present at birth in the newborn infant; plasma (a levels in cord blood range from approximately $10-11.5 \mathrm{mg} / 100 \mathrm{ml}$. exceeding plasma Ca levels in maternal blood (7). In most normal full term neonates there is a progressive decline in plasma (a levels toward the lower range of values $(8.5-10 \mathrm{mg} / 100 \mathrm{ml}(5))$ during the first $48-72 \mathrm{hr}$ of life. The decrease is more pronounced in LBW infants. In a recent survey. Rossli and Fanconi (22) observed that $53 \%$ of $174 \mathrm{~L}$.BW infants reached serum $\mathrm{Ca}$ levels below $7 \mathrm{mg} / 100 \mathrm{ml}$ during the 3 first days of life; this is in agreement with our present findings in the control group of LBW infants not receiving calcium infusion. Another interesting aspect of the postnatal changes in serum $\mathrm{Ca}$ in LBW infants is the fall occurring during the very early hours of life; in our control group of infants the mean \pm SD serum Ca values were, respectively, $7.0 \pm 0.51 \mathrm{mg} / 100 \mathrm{ml}$ at $10-1+\mathrm{hr}$ and $6.57 \pm$ $1.07 \mathrm{mg} / 100 \mathrm{ml}$ at $22-26 \mathrm{hr}$. Assuming that in most of these infants serum $\mathrm{Ca}$ in cord blood was above $10 \mathrm{mg} / 100 \mathrm{ml}$, it is clear that the decrease in serum Ca takes place essentially during the first $10-26 \mathrm{hr}$ of life.

Because we found in preliminary attempts that calcium infusion with 10 or $25 \mathrm{mg} / \mathrm{kg} /$ day calcium as calcium gluconate was insufficient to prevent this early fall in serum $\mathrm{Ca}$ in LBW infants. for the present study we used a continuous infusion of $35 \mathrm{mg} / \mathrm{kg} /$ day calcium. None of the $25 \mathrm{LBW}$ infants infused with this amount of calcium demonstrated any local or general complications. In the great majority of the infants receiving calcium infusion the serum (a levels remained above $7 \mathrm{mg} / 100$ ) $\mathrm{ml}(23 / 25)$. indicating that continuous infusion with $35 \mathrm{mg} / \mathrm{kg} /$ day calcium gluconate is efficient in preventing the early decrease in serum Ca of LBW infants. It may be of significance that the only infant who demonstrated an increase of serum $C$ : above $10 \mathrm{mg} / 100 \mathrm{ml}$ was a small for gestational age term infant As indicated by the finding of a positive correlation between serum $C$ a levels and gestational age in the control group. LBW term infants tend to present a smaller postnatal decrease in serum Ca than LBW premature infants; therefore, the term infants may be more sensitive to $C$ a infusion than the prematures. This suggests that a $\mathrm{Ca}$ amount smaller than $3.5 \mathrm{mg} / \mathrm{kg} / \mathrm{day}$ should be used in the small for gestational age term infants

Serum magnesium was significantly higher in the group of LBW infants receiving calcium infusion than in the control group; furthermore, positive correlations between serum (a) and serum $\mathrm{Mg}$ levels were found in the former group and not in the latter. The significance of these findings is not clear. A positive relationship between serum (at and serum $\mathrm{Mg}$ levels has been observed previously during the neonatal period (26); this relationship seems to indicate that extracellular $\mathrm{Mg}$ is subjected to the same physiologic and pathologic inferences as Ca $(7,26)$. In our study there were no remarkable differences in serum $\mathrm{PPTH}$ and serum $\mathrm{iC}$ T between the calcium group and the control group, suggesting that neither PTH nor ( $T$ was responsible for the changes in serum $\mathrm{Mg}$. A mechanism of either competitive inhibition or simple interdependence between magnesium and calcium is known to exist at the renal tubular level (3.3); the increase in extracellular $M g$ induced by calcium infusion suggests that such a mechanism may be active more generally at the cellular level in the low birth weight infants.

By contrast, it is of interest that LBW infants with Ca infusion showed no difference in serum $P$ levels as compared with control LBW infants. This suggests that calcium deposition as phosphate salts in bones was not increased by the (a supplementation. This is a rather unexpected finding if we consider that during the last months of gestation the fetus retains a large amount of calcium in the range of $10(0-150) \mathrm{mg} / \mathrm{kg} / \mathrm{day}(21)$ which mostly contributes to the skeletal mineralization. Thus our findings indicate that some limitation of the bone mineralization takes place during the early hours of life in LBW infants. This may result from a reduced synthesis of the organic matrix of bone because of the limited amount of protein available. On the other hand, it is possible that some hormonal factors intervene directly to inhibit the mineralization process.

Detectable levels of serum iPTH were present in all infants in both groups at $1-3 \mathrm{hr}$ of age with mean values slightly higher than in normal control adults or children. Furthermore. serum iPTH levels increased steadily in most infants from $1-3 \mathrm{hr}$ to $44-48 \mathrm{hr}$. These data confirm our previous findings in a group of $55 \mathrm{LBW}$ infants (8), and are in agreement with the results obtained by Fleischman and coworkers (15) in preterm rhesus monkeys. Thus in most LBW infants. unlike normal full term infants (7), there is good evidence that parathyroid glands are active immediately after birth. It is of interest that no significant differences in mean serum iPTH levels were observed between the two groups of infants. although they demonstrated a marked difference in mean serum (a levels. This indicates that continuous infusion with $35 \mathrm{mg} / \mathrm{kg} /$ day calcium has no suppressive effect on the parathyroid function in the majority of the LBW infants; the explanation may be that despite the Ca infusion. serum (a levels remained below the normal range in the majority of the infants.

However. it may be of significance that 6 of 25 of the LBW infants with calcium infusion as compared with 1 of 16 infants of the control group did not show an increase in serum iPTH levels over the $1-3 \mathrm{hr}$ or $10-14 \mathrm{hr}$ basal values; this may indicate that in some infants the parathyroid function was depressed by the calcium infusion. On the other hand. the fact that mean serum iPTH levels were not increased in the control group as compared with the calcium group, in spite of much lower serum (a levels, suggests that there exists some limitation of the parathyroid activity in the LBW infants during the first $48 \mathrm{hr}$ of life. This is consistent with the observations of David and Anast (7) which show that there was no increase or a limitated increase in circulating iPTH during the acute hypocalcemia induced by exchange transfusion in infants younger than $48 \mathrm{hr}$.

Elevated levels of plasma iCT have been described during the neonatal period $(3,6,10,24)$. Bergman et al. (3) observed an increase in plasma iCT during the first day of life in nine newborns of diabetic mothers and five control full term infants; Samatan et al. (24) reported high levels plasma ic"l in young newborn infants; Garel (16) found an increase in serum iCT levels between $1+$ and $24 \mathrm{hr}$ of life in the lamb. Both groups of our LBW infants showed a marked increase in serum iCT between $1-3 \mathrm{hr}$ and $10-1+\mathrm{hr}$ of life. The significance of this increase is unclear but it may contribute to the early hypocalcemia of the LBW infants as suggested by the negative correlattion observed between serum Ca and serum iC T levels. We did not find any significant differences in mean serum iC T levels between the infants receiving calcium infusion and the control infants. which suggests that continuous infusion with $3.5 \mathrm{mg} / \mathrm{kg} /$ day calcium does not result in an increased secretion of calcitonin. However. the tendency toward higher serum iCT level at $44-48 \mathrm{hr}$ of age in the infants receiving calcium as compared with the control infants may indicate that in some infants the calcitonin secretion was sustained by the calcium infusion.

\section{(ONCLUSION}

The prophylactic administration of continuous intravenous calcium gluconate on the hasis of $35 \mathrm{mg} / \mathrm{kg} / 24 \mathrm{hr} \mathrm{Ca}$ limits the postnatal depression of serum Ca in L.BW infants during the first $48 \mathrm{hr}$ of life. It has no overall adverse effect. It does not appear to depress the parathyroid activity in the majority of the infants. It has no significant influence on the postnatal calcitonin secretion.

\section{REFERENCES AND NOTES}

1. Abithol. C. L., Feldman. D. B.. Amman. P. A.. and Rudman. D.: Plasma aminoacid patterns during supplemental intravenous nutrition of low birth weight infants. J. Pediat. 86: 766 (1975). 
2. Amaud. (. D.. Tsao, H. S.. and Littledike, T : Radioimmunoassaty of human parathyroid in serum. J. ( lin. Invest..50:21 (1971).

3. Bereman. L.. Kjelimer. I.. and Selstam. U.: (alcitonin and parathyroid hormone relation to early neonatal hypocalcemia in infants of diabetic mothers. Biol. Neonat.. 24: $151(1974)$

4. Conaway. H. H., and Anast. ( . S.: Double antibody radiommunoassay for parathyroid hormenc. J. Lab. (lin. Med.. 8.3: 129(1974)

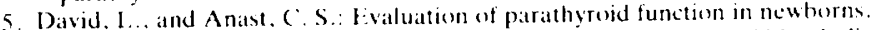
In: B Frame A M Parfitt, and H. Duncan: (linical Aspects of Metabolic Bune Discase. p. 6h1 (Excerpta Medica Foundation. Amsterdam. 1973).

6. David. L.. and Anast. ( S.: Scrum immunoreactive calcitonin (iC $T$ ) in newhorn [Abstr l Pediat. Res. 7: 386 (1973).

7. David $L$ and Anats ( $S$ : Calcium metabolism in newborn infants: The interclationship of parathyroid function and calcium, magnesium and phosphorus metabolism in normal, sick, and hypocalcemic newhorms. J (Cin Invest $54.287(1974)$

8 David I Salle B (hopard, D... and Frederich. A. Parathyroid function in low birth weight newborns during the first 48 hours of life. In: L. Stern and B. Fris Hansen: Symposium on Intensive Care of the Newborn, p. 107 (Masson Publishers. New York. 1976).

4. Dietrich, F. M. Hunziker, W. H., and Fisher. J. A.: Synthetic human calcitonin: Analysis of antibedies obtained from various animat species: and determination of immunorcalive hormone in human sera. Acta Endocrinol. $80: 465(1975)$

10. Dirksen. H. ('.. and Anast. ('. S.: Interrelationship of serum immunoreactive calcitonin ( $\mathrm{K}(\mathrm{T})$ and serum calcium in newborn infants. Pediat. Res.. IO) $408(1976)$.

11. Dubowitz. 1.. M. S.. Dubouitz V., and Coldberg. ( .. (Cinical assessment of gewationid age in the newborn infant. J. Pediat.. 77: 1 (1970)

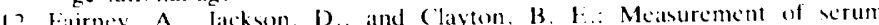
parathyroid hormone. with particular reference to some infants with hypor calcemiat. Arch. Dis. (bildhood. 48: $419(1973)$

13. Fisher, J. A.. Binswanger. U.. Dietrich. F. M. Human parathyroid hormone Immunological characterization of antibodies against a glandulat extract and the sunthetic amine-terminal fragments $1-12$ and $1-34$ and their use in the defernination of immunoreactive hormone in human sera. J. Clin. lnvest. .54: 1.382 (1974)

14. Fiske. ('. H... and SubbaRou. Y.: The colorimetric detemination of phospher rus. J. Biol. (hem.. 66: $375(1925)$

15. Feischman. A. R. Lerman. S.. Oakes. (i. K. Ipstein, M. F.. (hez, R. A. and Mintz. D. H. Perinatal primate parathyroid hormone metabolism. Biol. Neonat . 27: 40)(1975).

16. Garel J. M. Roble physiologique de la calcitemine dans le developpement pre et postnatal (These. Paris. 1975. Docteur en Sciences Naturelles).

17. (iindler. E. M. and Heth. D) A.: Colorimetric determanation with bound "calmagite" of magnesium in human blosd serum. Clin. (hem., 17: 66? (1971).

18. Gindler. I: M. and king. J. 1).: Rapid colorimetric determination of calcium in hiologic fluids with methylthymoblue. Amer. J. (lin. Path.. 58: 376 (1972).

19. Lubchencho, 1. ()., Hansman. ( .. Dressler. M.. and Boyd. B.: Intra-ulerine growth as estimated from liveborn hirth weight data at 24 to 42 weeks of gestation. J. Pediat...32: 793 (1962).

20. Nervez. (. T., Shott. R. J.. Bergstrom. N. H.. and Williams, M. I.. Prophylixis against hypocatcemia in low birth weight infants requiring picarbonate infusion. J. Pediat. 87: $439(1975)$

21. Radde, I. G.. Parkinson, D. K.. Hoffken B.. Appiah. K. E.. and Hanley W B.: Calcium ion activity in the sick neonate: Effect of bicarbonate administration and exchange transfusion. Pediat. Res., 6: 4.3 (1972)

22. Rosli, A . and Fanconi. A.: Neonatal hypocalcemia: "Farly type" in how birth weight newborns. Helv. Paediat. Acta. 28: 443 (1973)

23. Salle, B.. and Vercherat. M.: Alimentation intraveincuse supplementante ches le premature de moins de $1500 \mathrm{~g}$. Arch. Frang. Pediat ., 32: 27 (1975) 24. Samatan, N. A. Anderson. (i. D). Adam-Maync. M. E.: Immunureactive calcitonin in the mother. neonate, child and adult. Amer. J. Obstet Ciynecol.. 121: 622(1975)

25. Siguard-Anderson. (). Engel. K.. Jorgensen. K.. and Astrup. P.: A micromethod of determination of pft. ( $(0)$, tension. base excess and standard bicarhonate in capillary hlood. Scand. J. Clin. Lab. Invest.. 12: 172 (1960)

26. Snodgrass. (i. J. A. 1.. Stimmer. 1.. Went J.. Ahrams, M. I... and Will. I: J.: Interrelations of plasma calcium, inorganic phosphate. magnesium, and protein over the first week of life. Arch. Dis. ('hildhood. 48: 279 (197.3).

27. Suser, P. R.: The intensive care of the newly born. Monographo in Pediatrics. No. 6. p. 47 (S. Karger. Basel 1475).

2x. Tashijan, A. H. Jr.. and Voelkel. F. F.: Human calcitonin: Application of affinity chomategraphy. In: B. M. Jaffe and H. R. Bchrman: Metherds of Hormone Radioimmunoassay. (Academic Press. New York. 1969$)$.

29. Tosoley. W. M.: Idiopathic respiratory distress syndrom. In: S. S. (icllis and B. M. Kagan: (current Pediatric Therapy. p. $7 \times 2$ (W. B. Saunders Company. Philadelphia, 197.3)

30. Tiang, R. ( . (hen. 1. W.. Friedman, M. A.. and (hen 1.: Neonatal parathyroid function role of gestational age and postnatal age. J. Pediat. $8.3: 72 x(1973)$.

31. Thang, R ( Kleinman, 1. T.. Sutherland. J. M., and Light. I. I. Hypocalcemia in intants of diabetic mothers. J. Pediat . 80):38+ (1972)

32. J sang. R. (.. I.ight, I. J. Sutherland, J. M.. and Kleinman. L. T.: Possible pathogenic factors in aeonatal hypocalcemia of prematurity: The role of gestation, hyperphosphatemia, hypomagnesemia. urinary calcium loss and parathermone responsiveness, J. Pediat., $82: 423(197.3)$

33. Walser. M.: Renal discrimination between alkaline earth cations. J. Clin Invest.. 40: $1087(1901)$

34. Weichelhatum. T, F: An accurate and rapid method for the determinations of proteins in small amount of hlood scrum plasma. Amer. J. (lin. Path.. 16: $40(1946)$

35 Results from this control group were previously analyzed and have been putlished ueparately: David, 1... Salle, B.. (hopard, P.. and (irafmever. 1). Studies on circulating immunoreactive cilcitonin in low birth weight infants during the first to hour of life. Helv. Pitediat. Actit, 32: 39 (1977).

36. This study has been approved by an ad hoc research committec in the Unite Inserm (1.34. Informed parental consent was obtained.

37. This work was presented in part at the Annual Meeting of the American Socicty for Patediatric Rescarch. St. Lesuis. Missouri. April l976.

38. The authors are indebed (o) Dr. (onstantine S. Anast of the Department of Pediatrics. University of Missouri. (olumbia. Missouri for his invaluable gift of PTH antiscrum and purified bovine PTH 10 Dr. Rittel and Dr. Mater (Cihat. Basel. Switacrland) for their gitt of synthetic human ("T. and (1) Dr Dictrich ( (ibat. Basel) and Dr. Fisher (University of Zurich. Zurich. Suiverland) for their gift of ("T antiserum. The authoss wish to express their appreciation for advice and for the translation of Professor P. R. Swyer (Ioronto). for statistical analysis of $\mathrm{M}$. Biren (Service Informatique des Hospices (ivils de L.yon), for help of the staff of the newborn nursery. and for the secretarial assistance of Miss M. Pastor.

39. Ihis research was supported by a contrat de recherche daction themattique Inserm $74+462287$ and by the Conseil Scientifique of University Claude Bernard-Lyon.

41) The present address of Dr. L. David is: Lnite de Recherches Endocriniennes et du metabolisme de leenfant, Hôpital Debrousse. 690015 Lyon, France

41. The present address of Dr. D). (. (irafmeyer is: I aboratoire de Biochinie Hopital lidouard Herriot, 69374 L yon (cedex 2). France

42. Requests for reprints should be addressed to: B. L. Salle. M.D. Neonatal Department. Hopital Ldouard Herriot. 69374 lyon (edex 2 (1rance).

43. Received for publication December 21,1976

44. Accepted for publication March 15, 1977 